article/n/urovni-analiza-tekstovoy-emotivnosti-na-primere-tekstov-hudozhestvennogo-stilya. $\quad$ (дата звернення 23.01.2020)

5. Болотнова Н.С. О связи эмотивного и эстетического кодов поэтического текста // Человек в коммуникации: от категоризации эмоций к эмотивной лингвистике : Сборник научных трудов, посвященный 75-летию профессора В.И. Шаховского. Волгоград, 2013. С. 257-263.

6. Нашхоева М.Р. Лингвистическая концепция эмоций и эмотивности текста // Вестник Южно-Уральского государственного университета, 2011. № 1. С. 95-98.

7. Воробьёва О.П. Вирджиния Вулф и поэтика инсайта // Горизонты современной лингвистики: Традиции и новаторство : Сборник в честь Е.С. Кубряковой. Москва, 2009. С. 764-776.

8. Редька І.А. Емотивний поворот у віршованому тексті: лінгвопоетична перспектива (на матеріалі лірика Майї Анжелу) // Наукові записки. Серія : Філологічні науки. Кіровоград, 2016. Вип. 145. С. 474-479.

9. Редька І.А. Емотивність англомовної трансжанрової пасторалі // Науковий вісник Східноєвропейського національного університету імені Лесі Українки. Серія : фрілологічні науки. Луцьк, 2016. № 6 (331). С. 135-141.

10. Margaret Alice. To Love A Scorpion. URL: https://www.poemhunter.com/poem/love-s-beautiful-loveuntainted-love-unassuming-mck-love-a-scorpion-needs. (дата звернення 23.01.2020).

11. Єрмоленко С.Я. Емоційна лексика // Українська мова : Енциклопедія / Укл.: В.М. Русанівський, О.О. Тараненко, М.П. Заблюк. Київ : Українська енциклопедія, 2000. С. 157-158.

12. Харкевич Г.І. Відображення стану тривоги персонажа в англомовній художній прозі: семантико-когнітивний та наративний аспекти : автореф. дис. ... канд. філол. наук : 10.02.04. Київ, 2007. 24 с.

13. Piotrovskaya L. Speech production: emocio vs racio // 45th International Philological Conference (IPC 2016) Advances in Social Science, Education and Humanities Research (ASSEHR). Volume 122, 2016. P. 427-431.

14. Stevens W. The Planet on the Table. URL: https://www.poemhunter.com/poem/the-planet-on-the-table. (дата звернення 23.01.2020).

15. Волкова П.С. Эмотивность как метод постижения смысла художественного текста: вербальное и невербальное // Человек в коммуникации: от категоризации эмоций к эмотивной лингвистике : Сборник научных трудов, посвященный 75-летию профессора В.И. Шаховского. Волгоград, 2013. С. 263-281.

16. Редька І.А. Емотивні зсуви в образних просторах поетичного тексту (на матеріалі вірша Майї Анжелу «Caged Bird») // Doctrina multiplex, veritas una : збірник праць до ювілею Ізабелли Рафаїлівни Буніятової. Київ, 2018. C. 398-410.

17. Морозкина Е.А., Хамматова С.Р. Выражение эмотивности в художественном тексте (на материале романа У.Г. Симмса «Мартин Фабер») // Вестник Башкирского университета, 2015. Т. 20. № 1. С. 172-178.

УДК 808.51

DOI https://doi.org/10.32782/tps2663-4880/2020.13-2.32

\title{
DEPICTION OF ELECTORAL NOMINATION \\ IN TEXTS OF ENGLISH-LANGUAGE ONLINE NEWS
}

\section{ВІДОБРАЖЕННЯ НОМІНАЦІЇ ВИБОРНОСТІ В ТЕКСТАХ АНГЛОМОВНИХ НОВИН}

\author{
Sydor A.R., \\ orcid.org/0000-0001-6287-561X \\ Teacher of the Department of Foreign Languages \\ of Lviv Polytechnic National University \\ Nanivskyy R.S., \\ orcid.org/0000-0002-3256-8886 \\ Teacher of the Department of Foreign Languages \\ of Lviv Polytechnic National University
}

The significance of media discourse as a powerful and popular means of communicative action today, the presence of numerous approaches to the interpretation of this term in the scientific environment makes it possible to give the characteristics of its content, structural and functional characteristics. From the point of view of the functional approach, the criteria for the determining the types of discourse are socially significant spheres of communication and speech practice, such as science, education, politics, medicine, mass media. In this case, media discourse can be regarded as a collection of texts that function in the field of mass communication. The terms "computer discourse" and "electronic discourse" 
are absolute synonyms, since they mean communication through a computer. "Internet discourse" is understood as communication in the Global Network and is a kind of network discourse, which besides communication on the Internet also includes communication in other, in particular, local area networks. Thus, these types of discourse are in hyper-hyponomic relations, where the communication channel determines the computer (electronic) discourse acts as a hyperonomism and the communicative environment. Such monosemantics does not exist between computer and virtual discourse. Virtual discourse is understood to be narrower than computer one, since the latter is not just communication with a computer, but also communication between a person and a computer. In addition, computer discourse is characterized by the direct contact of communicators, which is impossible in virtual communication, where the communication partner is largely conceived by our consciousness. One can speak of a peculiar combination of the existential reality of a person and society with the media reality. Therefore, the taxonomy of this type of factors is inherent in each channel of transmission. The mass media communications directly affect the consciousness of people and the development of society by the very fact of its existence. The imperfection of the taxonomy of media discourse is explained by the presence in its structure of a large number of different-factor factors: here, at the same time, are process and result, knowledge and communication, dynamism and concentration, influence and resistance, cause and effect, interests of the addressee and the addresser.

Key words: nomination, election, electoral, internet news, BBC.

Значення медіа-дискурсу як потужного та популярного сьогодні засобу комунікативної дії, наявність численних підходів до трактування цього терміна у науковому середовищі дає змогу дати характеристики його змістових, структурних та функціональних характеристик. 3 точки зору функціонального підходу, критеріями визначення видів дискурсу є соціально значущі сфери спілкування та мовленнєвої практики, такі як наука, освіта, політика, медицина, засоби масової інформації. У цьому випадку медіа-дискурс можна розглядати як сукупність текстів, які функціонують у сфрері масової комунікації. Терміни «комп'ютерний дискурс» та «електронний дискурс» $є$ абсолютними синонімами, оскільки вони означають спілкування через комп'ютер. «Інтернет-дискурс» розуміється як комунікація в глобальній мережі та є різновидом мережевого дискурсу, який, крім спілкування в Інтернеті, включає і спілкування в інших, зокрема, локальних мережах. Таким чином, ці типи дискурсу знаходяться у гіпергіпономічних зв'язках, де канал зв'язку визначає, що комп'ютерний (електронний) дискурс виступає як гіперономізм та комунікативне середовище. Такої моносемантики між комп'ютером та віртуальним дискурсом не існує. Віртуальний дискурс розуміється вужчим, ніж комп'ютерний, оскільки останній - це не просто спілкування з комп'ютером, а пілкування людини з комп'ютером. Крім того, комп'ютерний дискурс характеризується прямим контактом комунікаторів, що неможливо у віртуальному спілкуванні, де партнер по комунікації багато в чому задуманий нашою свідомістю. Можна говорити про своєрідне поєднання екзистенціальної реальності людини та суспільства з медіа-реальністю. Тому таксономія цього типу фракторів притаманна кожному каналу передачі. Комунікації ЗМІ безпосередньо впливають на свідомість людей та розвиток суспільства самим фактом його існування. Недосконалість систематики медіа-дискурсу пояснюється наявністю в його структурі великої кількості фракторів різного виду: тут одночасно є процес і результат, знання та комунікація, динамізм і концентрація, вплив і опір, причина та наслідок, інтереси відправника та адресата.

Ключові слова: номінація, вибори, виборність, Інтернет-новини, Бі-Бі-Сі.

Formulation of the problem. The representation of the elective discourse by the leading media is basic for the reflection of a public position, and serves as a tool for forming public opinion. The subject of appointment by the election is rather controversial and requires a detailed study by linguists and political scientists. The mentality of the country, which is the founder of the media or its temporary placement, affects the specifics of the presentation and submission of the most controversial issues of electing - the right to express opinions, the relevance of the behavior of political leaders to socially acceptable standards. In fact, this leads to disproportion of the public opinion and the position of popular media.

The BBC is the British Broadcasting Corporation, which is the largest TV and radio company in the world. During its existence since 1922, it has formed the reputation of a reliable source of information. Elections and everything that is associated with this topic has always raised the interest of readers, spectators, and listeners. The BBC has its own specificity in displaying a block of news.

Analysis of recent research and publications. Taking into account the popularity of the Internet, the interest of linguists in this phenomenon becomes obvious. Thus, linguocultural (O. V. Lutovinova) and gender specifics (A.N. Guyfullina, O.I. Goroshko, L.F. Kompantseva) of Internet discourse, its genre formats (O.Yu. Raspopyna, L.V. Samoilenko, O. O. Zemlyakova, S. V Zaborovska, S. A. Matveeva, S. S. Danylyuk, O. M. Galichkina) and linguistic design (N. O. Akhrenova, A. G. Avramova) are being studied. Such basic concepts of Internet communication as hypertext (O. S. Klochkova, S. G. Stroykov, N. V. Kolomiets, O. M. Galichkina), virtual communicative space (N. G. Asmus), linguistic personality of virtual communicant (N. G. Asmus, M. S. Ryzhkov) etc. are considered.

However, the analyzed literature does not adequately cover all aspects of the research direction. Therefore, for a more detailed analysis of the problem area of studies such topic of work was chosen.

Task setting. The purpose of the study is to characterize the specific features of the selection of the electoral nomination in the texts of the BBC English-language online news.

To fulfill the stated purpose of the study, the following objectives were set:

1. To characterize the features of the media discourse. 
2. To identify the characteristics of Internet discourse.

3. To analyze the $\mathrm{BBC}$ as a kind of Internet discourse.

4. To explore the features of electoral nomination in the BBC English-language online media.

The object of the study is the BBC News Online. The subject of the study is items of electivity in the texts of the BBC English-language Internet news.

Presentation of the main material. Responding to any innovative processes taking place in society, media discourse points to the development of society, its positive and negative changes in a certain period.

Media discourse is a functionally determined type of discourse, a set of processes and products of speech activity in the field of mass communication in all their diversity and the complexity of their interaction [12, p. 182]. This term is considered both as a thematically focused, socioculturally conditioned speech-minded activity in the media space [13, p. 16]. Media discourse is considered as the reality created by means of mass communication, mediating the production, storage and spreading of publicly important information [21, p. 15]. Media discourse is also interpreted as a hierarchically organized, multilevel complex of texts, in which texts of a smaller structural and content volume are included in larger text volumes (press, radio, television, Internet) [16, p. 138].

The main features of media discourse are group correlations (the addressee shares the views of his group); publicity (openness and orientation to the public); decent orientation (contradiction with the following discussion); staging and mass orientation, which involves simultaneous influence on several groups $[19$, p. 27-40].

An important principle of media discourse is also its orientation towards the addressee. The addresser must take into account the large number of components of the status of the addressee (age, gender, professional, social, cultural and other factors) that help to clarify and supplement the concept of "destination factor." A specific addressee, his picture of the world and linguistic consciousness, guides some media. Thus, the audience combines the same expectations concerning the form and content of communicative actions [5, p. 209].

There are such types of media discourse as publicistic, advertising and PR-discourse. As for journalistic discourse, it is defined as a kind of informational-orientational and institutional discourse, which is realized with the help of mass communication and involves a conscious and clearly expressed actual position of the author $[10$, p. 4]. For journalistic discourse, there is a presence of two communi- cants - the author and the recipient. The journalistic discourse transmits the information together with its assessment by the author of the article. First of all, the texts of journalistic discourse can cover a large number of recipients. Information received through the channels of journalistic discourse, contributes to the formation of the political, linguistic, scientific, naive picture of the world in the public consciousness $[5$, p. 30].

Talking about the classification of types of media discourse through the channels of implementation, thus, according to the predominance of the specific means of communicative influence - visual, audio and audiovisual, the television, radio and computer discourses are distinguished. They have structural, stylistic, compositional-speech characteristics and they are forms of the general social-language context of the era. Television and radio discourses are thought to be relaxing and unofficial [2].

The authors of television and radio create a significant image of live speech. The speaker (announcer) and the viewer (listener) are at different points of space and time, they cannot adjust what was said and heard (for example, to ask the question). The rate of submission (selection) of information does not depend on the viewer (listener). Speaker's status is official, viewer's (listener's) one is unofficial [22, p. 139]. Computer discourse can be both person-oriented (communication via e-mail) and status-oriented (conferences devoted to various topics: politics, sports, medicine, science, etc.). It is characterized by a variety of subjects of speech and the variability of the used language means [17, p. 138].

All research tasks are solved through the prism of a discursive approach, the methodological principle of which is anthropocentrism - the heuristic principle of the consideration of language and speech in connection with the thinking of a person, which reflects its internal state, human, national and cultural, social values [5, c.47].

Y. S. Stepanov emphasizes that discourse is a "language in speech", presented in the form of a special social identity. Discourse really does not exist in the form of its "grammar" and its "lexicon". Discourse exists primarily and mainly in texts, but those that give rise to special grammar, special vocabulary, special rules of usage and syntax, special semantics and finally - a special world. This is a "possible (alternative) world" [15, c. 95]. One of such alternative worlds is the world of the Internet.

The active development of problems of communication mediated by the electronic information technology channel and the lack of a common terminology for the above-mentioned research in the linguistics 
calls for the clarification of the content and delineation of such concepts as "virtual discourse", "computer discourse", "electronic discourse", "network discourse" and "Internet discourse" [3].

Virtual discourse is interpreted more broadly than computer one, since communication in the virtual reality is created through not only the computer, but also other means of communication [5].

At the same time, electronic (computer) and virtual discourses denote arrays that include not only Internet texts, but also texts on non-paper media (audiobooks, movies, music discs, games, programs), multimedia devices (smartphones, communicators, iPod, eBooks), etc., and are much wider than the Internet discourse [20, c. 129].

In modern linguistics, Internet discourse is interpreted differently. It is understood as:

- the cognitive-communicative space of the Global Network, in which the means of the electronic data transmission channel and the hypertextual mechanism of their structuring and routing with the help of (para) verbal means provide communicative interaction, which is characterized by the replacement of the real image with the invented one [20];

- the text that exists in the Internet system and in which the persuasive communicative installation implicitly reflects the subjective-personal author's position, modeled with psychological, linguistic and technological factors [19];

- the process of creating texts together with pragmalinguistic, socio-cultural, psychological factors; purposeful social action, which includes the interaction of people and mechanisms of their consciousness - cognitive processes [5];

- complex text system, caused by extra-linguistic socio-cultural factors and the specific situation of entering into speech communication with the help of a computer and other electronic devices both users of the Internet network and users with a discursive Internet space [9, p. 3].

In our understanding, Internet discourse is an array of electronic, audio and video texts combined with extralinguistic factors linked by a hyperlink system, access to which provides access to the Internet using a computer or alternative multimedia devices.

Linguistics understands structure as the generalized notation of the invariant features of the sound, phonological, morphological and morphonological characteristics of the language in terms of their correlation with each other, that is, in terms of the laws of the use of units of the lower level for the design of higher units; the internal organization of language as a semiotic system, which limits the freedom to reproduce its elements, which man- ifests itself in the unequal frequency of their use, limiting their compatibility and generates redundancy [14, p. 58].

Extrapolating the notion of structure in the Internet communication, it can be understood as a well-organized hierarchical system, in which the navigation between parts is provided by moving from lower to higher units and vice versa.

The main requirements for organizing the creation of information within the framework of Internet discourse is the clarity of the distribution of the text field into certain segments and the provision of internal links between them [16, p. 10], which becomes possible due to hypertext - a kind of text document, the individual parts of which are linked through hyperlinks. Hyperlinks and texts of messages as structural hypertext elements acquire a linguistic representation in the form of an electronic document. Hyperlinks of the Internet discourse are the enumeration or list of keywords or phrases; underlined and highlighted keyword (phrase). The main function of hyperlinks is to enable navigation through the electronic text $[10$, p. 8$]$.

The concept of hypertext arose recently in connection with the study of electronic texts. Wellknown American sociologist, philosopher, and pioneer of information technology T. Nelson first used the term "hypertext" in the 1960's to designate texts that have an electronic form, as a radically new method of information technology and a new method of publication [22, p. 47].

However, hypertext as a phenomenon had existed long before the era of the Internet.

Atypical hypertext for the network time is a collection of Bible texts. They can be read not only linearly, but also nonlinearly, following the order of associative references and parallel places, which was explicitly pointed out in many editions of the books of the Old and New Testaments, that is, hypertextualy [10]. In addition, the hypertext includes encyclopedias, reference books, dictionaries, etc., since they contain links to other texts. The fundamental difference between the electronic hypertext and the traditional one is that the former is distinguished by its openness and incompleteness, which allows the participants to add and modify the source text [15, p. 79].

A number of nominative signs of the English language represents the sources of information: characterization (general names), individualization (own names), quantitative (quantitative units) [19, p. 37].

Individualization signs are represented by proper names, which denote individuals and objects, isolated from a number of homogeneous ones [15, p. 91]. Variety of proper names includes the address names 
involved into the media constructing of the referents [5, p. 104] and classifiers, which by naming posts, place of work, country, localize the individual in the public hierarchy [5, p. 107].

Characterization is represented by common names that depict homogeneous objects [15, p. 91]. Quantitative units are represented by cardinal numerals as signs, which express the concept of quantity and number [1, p. 46-48].

Thementioned examplesare enough to show thetight connection between different aspects of the political communication with the study of media discourse [22].

Conclusion. Thus, we can make the following interferences of the study:

1. Postulating the idea that in general discourse does not have clearly defined boundaries, it should be emphasized that this is an open structure characterized by incompleteness, repetition, dynamism, and media discourse in particular, due to its main goal - the reflection of the life of society - has a wide area for the formation of a clear systematized classification system in linguistics.

2. Scholars set different criteria and components of this discourse in the basics of their classifications: channels of information transmission, form of communication, socio-functional orientation, strategy of presenting the information, tone of communication, etc. Although these factors are fundamental and scientifically reliable for this research work, it cannot be argued that the above-mentioned classifications satisfy modern linguistics. As we see from the mentioned typologies, the same criteria appear in different classifications, which makes the typology of media discourse somewhat opaque and confused.

Consequently, taking into account the multifaceted nature of this phenomenon (that is, the reflection of all sides of human existence and the development of society), its complex structure, functional features, it is almost impossible to conclude a comprehensive and detailed taxonomy of media discourse.

\section{REFERENCES:}

1. Alcott H. Social Media and Fake News in the 2016 Election - Stanford Journal of Economic Perspectives Volume 31. № 2. 2017. P. 211-236.

2. Alefirenko N. F. Cultural linguistics. Valuable and semantic space of language. [Textbook] / N. F. Alefirenko. M.: Flinta, 2010. $-288 \mathrm{p}$.

3. Anashkina E. V. Mechanisms of a functional categorization of verbs at metonymical transfer in Englishspeaking art discourse / E. V. Anashkina // Studies about languages. - 2012. - № 20. - P. 37-42.

4. Batsevich F. S. The fundamentals of communicative linguistics / F. S. Batsevich. - K.: Academy, 2004. -346 p.

5. Bell A. The discourse structure of news stories / A. Bell // Approaches to Media Discourse. - Oxford: Blackwell Publishers, 1998. - P. 64-104.

6. Bezpechny I. A. Theory of Literature / Foreword by R. Semkiv, L. Nelipa, 2009. -388 p.

7. Bezpechny I. A. Theory of Literature / I. A. Bezpechnyi. - K.: Smoloskyp, 2009. -338 p.

8. Cohen-Almager R. Speech, Media and Ethics. The Limits of Expression / R. Cohen-Almager. - Palgrave, 2001. $-217 \mathrm{p}$.

9. Dalton R. The Civic Culture Transformed: From Alegiant to Assertive Citizens / R. Dalton, C. Welzel. New York: Cambridge University Press, New York, 2014. - 325 c.

10. Denisyuk S. G. Technological measuring of the political communication: monography / S. G. Denisyuk. Vinnytsya: VNTU, 2012. -392 p.

11. Jacobs F. Forum: European Parliament Elections in Times of Crisis / Jacobs // Intereconomics. ZBW-Leibniz Information Centre for Economics. - 2014. - № 1. - C. 4-29.

12. Klyachin A. K. Political communication as the factor of the transformation of the political values $/$ A. K. Klyachin. - Dhipropetrovsk: Dnipropetrovsk National University, 2007. - P. 19.

13. Maat H. P. Editing and genre conflict: how newspaper journalists clarify and neutralize press release copy / Henk Pander Maat // Pragmatics. - 2008. - Vol. 18, N 1. - P. 87-113.

14. McLuhan M. The understanding of media: an external expansion of a person. / McLuhan M. - M.: CANONpress, 2003. $-464 \mathrm{p}$.

15. Mikhaleva O. L. Political discourse: the specificity of manipulation / O. L. Mikhaleva. - M.: "LIBROCOM", 2009. $-256 \mathrm{p}$.

16. Potapenko S. I. Modern English media-discourse: linguocognitive and motivative aspects / S. I. Potapenko [Monography]. - Nizyn: publishers of NSPU, 2009. - 391 p.

17. Ryan D. Understanding digital marketing: marketing strategies for engaging the digital generation / D. Ryan, C. Jones. - London: Kogan Page, 2009. - 272 c.

18. Social Media and Political Communication in the 2014 Elections to the European Parliament / [P. Nulty, Y. Theocharis, O. Parnet та ін.]. - London: London School of Economics, 2015.

19. Ufimtseva A. A. Lexical nomination (primary neutral) / A. A. Ufimtseva // Language nomination (types of denomination). - M.: Science, 1977. - P. 5-86. 
20. Brussels and the Eurobubble [Electronic source] // Marco Recorder. - 2015. - Available at: https:/ marcorecorder.com/brussels/.

21. Bykov I. Network political communication: Theory, practice and research. [Electronic source] / I. Bykov // Scientific e-library - Available at: http://elibrary.ru/item.asp?id=20235938.

22. Rendall A. The European Parliament elections - a 'social media election'? [Electronic source] / Rendall // BBC. - 2013. - Available at: http:// www. bbc.co.uk/democracylive/europe-25094624.

\title{
ЗАТЕМНЕННЯ МОТИВАЦІЇ ТА СЛОВОТВІРНІ КОНСТРУКЦІЇ ВІДДІЕСЛІВНИХ ПРИКМЕТНИКІВ У СУЧАСНІЙ НІМЕЦЬКІЙ МОВІ
}

\section{DIMMING OF MOTIVATIONAL STATEMENT AND WORD-FORMING CONSTRUCTIONS OF VERBAL ADJECTIVES IN MODERN GERMAN}

\author{
Ситюк В.В., \\ orcid.org/0000-0002-0002-1368 \\ студентка IV курсу \\ факультету лінгвістики та соиіальних комунікаиій \\ Національного авіаціийного університету
}

\author{
Кульчицький B.I., \\ кандидат філологічних наук, \\ дочент кафедри іноземної філології \\ Національного авіаційного університету
}

\begin{abstract}
У статті досліджується, що прикметники, структурно й семантично мотивовані дієслівною основою, являють собою об'єднану класом твірних основ мікросистему в словотвірній системі сучасної німецької мови з властивими тільки ӥй особливостями. 3 плином часу німецька мова модифікується під потреби сучасного суспільства. Темп зростання кількості саме віддієслівних прикметників високий, а вживаність об'єкту нашої роботи стає все більш буденною, необхідно провести комплексний аналіз характерних особливостей мікросистеми цього типу прикметників. Також слід дослідити як частотність вживання прикметників призводить до затемнення словотвірної мотивації словотвірних конструкцій та явище синхронної похідності. Проаналізувавши літературу та наукові роботи лінгвістів, пов'язані з вивченням віддієслівних прикметників, неможливо знайти точні відповіді та пояснення природи такого типу прикметників. Варто встановити також відношення синхронної похідності між дієслівними основами і відповідними суфіксальними прикметниками, так як це взагалі не було досі предметом дослідження. Використано два методи аналізу віддієслівних прикметників для вивчення їхніх особливостей. Основним методом у роботі виступає аналіз за безпосередніми складниками (БС). На його основі можливо виокремлення максимальних структурносемантичних відрізків у складі похідного слова, встановивши при цьому можливі причини виникнення труднощів відношень похідності. Семантичний принцип підходу до виявлення відповідних відношень похідності визначає методику словотвірного аналізу й у всіх інших випадках, коли аналіз за БС не дає позитивних результатів. Було також досліджено встановлення відношень синхронної похідності між дієслівними основами і відповідними суфіксальними прикметниками на основі слів із сусріксом - bar для спростування твердження про доцільність використання трансформаційного методу лише у випадку уточнення результатів. У ході виконаного дослідження було ще розглянуто питання методики моделювання та застосовано семний аналіз до дослідження словотвірного значення похідних слів.
\end{abstract}

Ключові слова: мотивація, затемнення мотивації, дериват, сема, словотвірний аналіз, синтегматика.

The article investigates that adjectives, structurally and semantically motivated on the verbal basis, are a unified class of generative foundations of the microsystem in the word-forming system of modern German with only its peculiarities. Over time, the German language was modified for the needs of modern society. The rate of growth of the number of verbose adjectives is high, and the utilization of the object of our work is becoming more commonplace, it is necessary to carry out a comprehensive analysis of the characteristics of the microsystem of this type of adjectives. It should also be investigated how the frequency of the use of adjectives leads to a dimming of the word-formation motivation of word-forming structures and the phenomenon of synchronous derivation. Analyzing the literature and scientific work of linguists related to the study of verbal adjectives, it is impossible to find accurate answers and explanations for the nature of this type of adjectives. The relation of synchronous derivation between verbal bases and corresponding suffixes should also be established, since this has not been the subject of research at all. Two methods of analysis of verbal adjectives were used to study their features. The main method in the work is the analysis of direct components (DC). On this basis it is possible to distinguish maximal structural-semantic segments in the composition of a derivative word while identifying possible causes of difficulties in the relationship of the derivatives. The semantic principle of the approach to identify the corresponding derivative relations 